\title{
Pastoral care and the agony of female singleness in the African christian context
}

\author{
M.E. Baloyi
}

Department of Practical Theology

Unisa

PRETORIA

E-mail: baloye@unisa.ac.za

\begin{abstract}
Pastoral care and the agony of female singleness in the African christian context

In our society the norm is that every adult should get married one day. This could imply that unmarried people do not feel welcome either in the community or the church. They may feel neglected or even like outcasts. It is a pity that the church, which also finds itself within the community, is composed of people who still continue to have the kind of attitude that excludes singles, even inside church circles. While churches run programmes that have a strong emphasis on marriage and family life, nothing is being done to address singleness and its related problems. As a result, singles often regard themselves as unimportant and worthless. This article is aimed at uncovering the role of the church through its leadership (pastors in particular) to assist and help to redeem the damaged image and self-esteem that singles may have in their respective communities and churches. The article focuses on singles in the African church and society. It is crucial that a church programme of care and counselling be structured in order to minister to persons who are separated, divorced, widowed or never married for whatever reason.
\end{abstract}

\section{Opsomming}

Pastorale sorg en die pyn van enkellopende vroue in 'n christen-Afrikakonteks

In ons samelewing is die norm dat alle volwassenes uiteindelik sal trou. Die gevolg hiervan is dat ongetroude mense dikwels in sowel die gemeenskap as die kerk onwelkom voel. Hulle mag dalk verwaarloos en selfs verstote voel. Dit is jammer dat die kerk, wat ditself midde-in 'n gemeenskap bevind, nog steeds uit 
mense bestaan met 'n houding wat enkellopendes uitges/uit laat voel, selfs binne kerklike kringe. Alhoewel kerke programme aanbied waarin sterk klem gelê word op die huwelik en die gesinslewe, word niks gedoen om enkellopendes en hulle probleme te hanteer nie. Gevolglik beskou enkellopendes hulleself dikwels as onbelangrik en waardeloos. Die doel van hierdie artikel is om die rol van die kerk te ontdek deur sy leierskap (veral predikante en pastore) en by te staan in sy rol om enkellopendes by te staan in die herstel van 'n seergemaakte selfbeeld wat hulle moontlik in hulle gemeenskappe en die kerk opgedoen het. Die artikel fokus op enkellopendes binne die Afrika-kerke en -gemeenskappe. Dit is van kardinale belang dat 'n kerkprogram geïmplementeer moet word vir die versorging en berading van afgesonderdes, weduwees en wewenaars, asook mense wat nooit getroud is nie, om watter rede ook al.

\section{Introduction}

The agony of singleness in the African christian church and community has been evident for a long time. Although the causes of singleness differ, the worrying factor is that not many of the challenges these people face have been addressed by the church. The causes range from divorce, hellish spouses (abusive partners), separation to death, and some of these issues, to a certain extent, cannot be avoided. The effects are damage to the self-esteem, withdrawal, loneliness, financial failure and unfaithful sexual relationships. This article tries to assess the causes of singleness and its consequences, with a view to determining how pastoral caregivers can assist to eliminate the problems that singles face in the African context. Even though some causes are natural, we need to have some way forward as pastoral caregivers on how singles can be accommodated and accepted in their situation in our communities and churches. Ultimately it should primarily be the duty of the church through its pastoral services to redeem the image of the singles. Single African people should feel accepted and accommodated in their community and church.

\section{Background}

Many research studies, books and articles have been written to indicate the importance of marriage. One Sotho idiom says: "Lebitla la mosadi ke bohadi" (the grave of a woman is in her marriage or her in-laws) (Kriel, 1991:27). This saying implies and emphasises that every woman must remain in the marriage even when conditions are difficult. The saying does not mention anything about singles, and on 
hearing this, some singles might feel neglected. This saying portrays every woman as an object of marriage, which means that a woman must or should be married. For this reason, marriage is often called the backbone of society (Kimathi, 1994:40).

Landman (2007:7) found that farmworkers surveyed found it extremely shameful to be without a sexual partner. Many people think that every normal person needs to get married. This puts a lot of pressure on those who are not married and hence remaining a single person in this context becomes one of the most difficult decisions of one's life. There are many reminders for women who are alone that they are not living a "normal" lifestyle (Reynolds, 2008: 123). The problems that are related to singleness are known, but not addressed by different churches. It is an undeniable fact that our church has a large number of young singles who are not specifically catered for. The opposite is also true, namely that a number of new marriages end in divorce as a result of people marrying just to avoid being single.

Single people in the African community are also subjected to social stigma. Some are suspected of having no intimacy feelings, and other older singles are suspected of witchcraft according to Phaswana (2005:1). Nothing positive is said about women who have broken marriages and being single is associated with being antisocial. The emphasis placed on marriage by customs and traditions teaches that a person must get married when they grow up. If this does not happen, a single adult person is not only unacceptable, but he/she also becomes a bad example in the community. The same attitude towards singles from other communities is found even in America. According to Dickerson (1995:90), some women studied said that their divorce had had a negative effect on them personally and their families, because singleness was not culturally acceptable in the Virgin Islands. Though our focus for now is on Africa, the problem seems to extend to different people in the world.

The above indicates how the agony of singleness affects some people. There are people who not necessarily get married because they want to, but because they feel the pressure of being single. Such marriages seldom last, since they will lack commitment which is needed for every marriage to survive. Some singles are uninformed about the fact that marriage and singleness are both honoured by God; hence they assume that without a mate there is no significance or purpose in life. That is why, according to Seccombe and Warner (2004:286), some women struggle to construct an independent identity in a social world that has viewed them 
as "relational", or dependent on men. This is one of the reasons why some singles have multiple sexual relationships, while others practise prostitution as one way to avoid singleness.

\section{Causes of singleness}

It is important to indicate why the causes of singleness should be part of this article. The first reason is that it is becoming very clear that singleness is something that people really struggle with, and that the church has not done enough to eliminate the feelings of uneasiness. It is my strong belief that without understanding what the causes of the problem are, it may become difficult to follow the arguments which try to solve it. The second reason is that since we have "singles who are not living single", according to Seccombe and Warner (2004:279), a short survey of the causes will assist our ability to define singleness in a particular context. Knowing the causes may also lead us to understand the variety of methods to be used to solve the challenges facing singles, as every cause may lead to thinking differently about the technique of dealing with individual problems.

\subsection{Death of a spouse}

Death has always been one of the unavoidable causes of being single. Seccombe and Warner (2004:286) indicate that women are more likely than men to be single, because they are divorced, widowed or separated. In other words, the death of a spouse (husbands in this context), which is of course a natural occurrence, leaves the wife without choice in becoming a widow. This state of being single is not a preferred choice or voluntary. Bird and Melville (1994:223) also list death as one of the causes of being single when they say that single parent families are created in a variety of ways, including separation, divorce and widowhood.

\subsection{Hellish spouses or hostile marriages}

Some spouses make it impossible for their partners to live with them, and so the partners decide to abandon the relationship. A marriage that is irreparably broken is sometimes caused by cruel or violent behaviour by either party. Of course, some of the behaviour results from alcohol and/or drug abuse, adultery or unfaithfulness by one party, according to Engelbrecht and Wentzel (1999:122). The view that only men are violent in marriages should be criticised, because both men and women can sometimes be violent. There are people who naturally make it difficult for their spouses to live with 
them. On the other hand, it should be understood that women are frequently seen as inferior to men. They must either marry or else they bring shame to the family and that leads to children out of wedlock and, de facto, single mothers.

One man was defending a case of wife-beating in the magistrate's court in Driefontein near Piet Retief in Mpumalanga and he asked: "Where am I wrong when I beat my own wife?" (Anon., 2007:10.) This statement indicates that there are still people in our communities who believe that wife-beating is the normal way of marriage, whereas it merely makes their partners feel betrayed in the marriage. In his research, Dreyer (2009:5) relates two stories of how some women were beaten, strangled and forced into sexual intercourse by their husbands who claimed that they should accept it, because they married them. The fact that this type of violence against women is a worldwide problem means that pastoral caregivers need to address it.

These examples show that domestic violence can and may be another reason why people choose singleness as their refuge. Many abusive marriages often end in divorce and singleness. Another story that indicates that some partners are abusing their wives in such a way that the women find themselves with no choice but separation, divorce and singleness, appeared in a Sunday Sun newspaper article (Anon., 2005:31). A woman was gang-raped by her own husband and two other men. According to the newspaper reporter, the husband sent two men to take his wife into the bushes, where he was the first to rape her in front of these men. Then later the other men raped her. This took place in Bethal, Mpumalanga. From these stories, we can see how some women regard divorce as a way to solve their problems. According to Collins (1988:365), if a marriage has been unhappy for a long time, its ending may bring at least a temporary sense of relief.

\subsection{Lack of interpersonal skills or fear of being hurt in close relationships}

Some people grew up in violent families, and their childhood experience about matters relating to marriage issues was very bad. This may have been because parents or guardians who raised them had bad relationships characterised by battles, quarrels and misunderstanding. These experiences might have influenced them negatively, causing them to fear any marital relationship. De Paulo (2006:135) shares a story of a young man whose parents ended their quarrels in a divorce. The young man fell in love with a girl who 
was very eager to get married soon. However, he was not interested in committing himself since his childhood experience of marriage relationships was a bad one. The proposed marriage did not continue, because the young man left the girl out of fear. "The guy, though had parents who divorced. He was scared by the experience and skittish about marriage." (De Paulo, 2006:135.)

De Paulo also mentions a book entitled, Why are there no good men left, which describes very bad things that take place in marriage relationships. Those who read the book without a critical mind may also end up being convinced not to enter into marital relationships.

\subsection{Gift of singleness according to Paul}

Although lifelong singleness has been a significant alternative to marriage throughout history, says Reynolds (2008:79), the focus on representations of women as actively choosing singleness, and enquiries into whether or not singleness has been deliberately chosen is relatively contemporary. Such singles are the same ones that Adams calls "blessed", writes Scanzoni (1995:159). These people prefer or choose to remain single and have not been subject to the circumstances mentioned above as causes for being single. According to Paul in 1 Corinthians 7:7-8 there is nothing wrong in staying single, particularly if such a person has a gift of being single. This means that being single is not just a wish, but also a gift.

\section{What are the challenges faced by singles?}

Discussing these challenges is not only important, but also meaningful since we are then directed into the real need for pastoral care for people. In other words, what single people go through is part of the responsibility of the pastoral counsellor. Bird and Melville (1994:113) urge that it is important that we identify the kinds of problems singles face in our marriage-oriented society and also describe the satisfaction of people in each of these interpersonal lifestyles. We need to know and understand how the singles feel through our counselling, which will help us to identify the challenges they face, and the ways of helping them.

\subsection{Loneliness}

According to Monaghan (1991:23), Christopher Martins speaks of loneliness as the leprosy of the day. He says that it affects the young, the old, the middle-aged, the bereaved, the healthy and the victims of AIDS, the divorced and the singles. In his Singles at the 
cross roads Hsu (1997:101) argues that loneliness may have nothing to do with singleness. He says:

We need to understand where our loneliness comes from, to realize that the cause of our loneliness could be far greater than simply being single. We must recognize that loneliness is not solved by marriage.

Hsu's view (1997:101) is echoed by the argument which says that there are married people who live in solitude. Hsu and Rosenzweig $(1992: 231)$ are proponents of this idea. They argue that there are married people who still live in loneliness as a result of the other partner being an alcoholic, for instance. This argument is also supported by Smith and Smith (2008:75), who understand that it is not the presence of the people that prevents loneliness, but it is the presence of a sense of self-adequacy. There are some married couples who do not even talk to each other except when one of them asks the other to pass the salt.

However, being single (outside the context of marriage) is the point of departure for this article and everything is taken from that context. It should also be understood that singleness can be defined differently according to different people and cultures. The article also focuses on the singleness among black Africans, which may differ from the situation Hsu describes. It is very important in this regard to also clarify the difference between singleness and loneliness. Singleness in this context is a state of being unmarried while loneliness is being alone, without someone to talk to. In this way loneliness is a general concept which includes all people (of al ages and both genders) while our discussion on singles focuses on the women who are not married or are divorced or widowed.

The author shares the same opinion as Koons and Anthony (1991: 115 ) when they say that "separated and divorced people most often feel an overwhelming sense of loneliness, as if they are the only persons going through this crisis". This statement not only confirms, but also emphasises that single people may indeed have a problem of being lonely which needs to be addressed pastorally and biblically. The author is of the opinion that Hsu avoids a challenge by underestimating the effects of being lonely.

In her book Alone in America, Louise Bernikow states that one of the most difficult things for any human to admit is loneliness (Fagerstom, 1996:33). It is good and advisable to remember that when working with singles, they may freely talk about the most intimate 
experiences of life and yet be unable to admit that they are lonely. Loneliness has been a problem from the beginning of time, because even God saw the importance of rescuing man from such a situation, as we read in Genesis 2:18. That is why Baloyi (2001:14) mentions that although everything that God made and declared as good (Gen. 1:31), the only thing that was lacking was a companion to man. This is an indication that loneliness (even if it is not caused by singleness) is something that everyone worries about. The very first challenge for almost every single person is loneliness (Landman, 2009:180).

In order to articulate clearly how bad loneliness is, and the fact that the impulse of each human heart is to seek closeness with another, Nicholson (2007:146) contends as follows: "Lonely individuals reach in the dark for whoever may alleviate solitude. Unless that need could be met, the alternative, for many women denied the solace of marriage, was undeniably tough." Lastly, even if loneliness is not caused only by singleness, as Hsu argues, there is a need to realise that since people differ, there are those whose singleness results in a loneliness problem and they need to be acknowledged and addressed.

\subsection{Period of denial}

One of the greatest obstacles when dealing with singles, explain Wicks and Parsons (2003:214), is a defence of denial. According to Monaghan (1991:39), some people like to pretend that everything is going well and deny anything bad or negative. It should be understood that an unrealistic optimism that too often uses denial may set us up for disappointment. Although Monaghan (1991:40) holds the view that defence mechanisms and denial can be a very important part of good mental health, the author is of the opinion that denial is a way of avoiding difficulties, responsibilities and realities of life. Fagerstrom (1996:138) feels that denial can be a first line of defence in that it lets a person grasp what has happened.

It is difficult to start a discussion with a single woman about her singleness, because most of them do not regard themselves as singles, especially in my community. Most of them believe that they need to be accommodated as second wives to their so-called "boyfriends", meanwhile these "boyfriends" are also married people. This implies that they regard it as being better to be accommodated in a polygamous marriage than being single. This is of course a new form of polygamy, which is not our focus for this article. A proper distinction is possibly needed between boyfriend and husband. In 
this context, I understand that a husband is someone that is legally married, whereas a man who visits a woman sometimes and these two are not legally married can be regarded as a boyfriend. In this way there are singles who spend their lives as married people, but without a husband in the true sense of the word. Such people make it difficult for a pastor and the community to place them between the singles and the married.

\subsection{Self-esteem damage}

Fagerstrom (1996:69) says that one of the most common struggles of single adults today is low self-esteem, and the problem is not limited to any particular economic, social, spiritual, cultural, racial, political or ethnic background. The definition of self-esteem is "to value highly" or "to have a great regard for". Consequently, persons with low self-esteem do not regard themselves very highly and do not think they are valuable. While I see people with low self-esteem as people who use crutches, Wicks and Parsons (1993:363) explain that they all too frequently "see themselves as unworthy or unlovable people who do not deserve genuine, sustained happiness in life".

Among the causes of low self-esteem, reports Collins (1988:318), community influences play an exceptionally important role, because it is in the community that a person can be encouraged, discouraged and manipulated. In other words, it is part of the community to make us what we are. Our community still considers being single as unusual, unfortunate, unnatural and even undesirable. Many negative terms are given to these people. In a Tsonga speaking community a male who has never been married is called nghwendzha and a female who has never been married is called dzinga-vukati (literally meaning: the one failed to get married). It is difficult to convey the literal meanings of these concepts, but the reality is that they strongly emphasise the unacceptable status of such people. No one would feel comfortable being called such terms, because they are very negative.

A divorced woman is called xivuya (literally meaning the one who returned from marriage). These terms do not have positive connotations and no one expects to associate him-/herself with them. These definitions give us a picture of how we should understand and view single people's most likely situation. The terms suggest that to be single is always a bad example in an African community. According to Phaswana (2005:1) in his unpublished research of the 
Venda speaking people in the north, to be single is like to be antisocial. He continued:

A single person is suspected of many things, lack of intimacy feelings and witchcraft are part of them. They are still looked upon as unusual, unfortunate and even undesireable. (Phaswaba, 2005:1.)

The communal life is also important to mention here since Africans would say: "I am, because they are." It is a fact, according to Scanzoni (1995), that society and its institutions, the church included, play a pivotal role in inflicting damage on one's self-esteem, particularly the low self-esteem that may result from being a single person.

Scanzoni (1995:150) indicates that in some churches, married persons are invited to weddings and parties as couples, whereas single persons are not allowed to bring a friend unless the wedding planners define their relationship as ongoing serious. Wicks and Parsons (2003:165) say that if a person's true self is unacceptable to themselves and others, and the false self is at odds with that person's authentic feelings and understanding of their own reality, self-hatred occurs. In other words, the person becomes stigmatised and feels unworthy. Rejection and disownment usually occurs and a healthy self-esteem may be a difficult, seemingly impossible achievement thereafter.

Some divorced women have many more psychological adjustments to contend with. A divorced woman in a documentary compiled by Dickerson (1995:90) explained the impact that her singleness after divorce had on her self-esteem:

You start to question yourself and you have to try and take all the pieces of the puzzle that make you and put them together again, because they are literally torn asunder from a divorce situation. You begin to wonder and have to work harder to get your self-respect back and your self-esteem.

The other important thing is to know that people with low self-esteem often lack inner peace and security and they are jealous and socially withdrawn. Self-hatred, self-criticism and self-rejection often characterise their lives. Those with low self-esteem, like singles, are likely to feel isolated, too weak, or unlovable to overcome their deficiencies and unable to defend themselves. 


\subsection{Economic failure to care for the family}

Wicks and Parsons (1993:331) confirm that the problem of economic failure is evident from some singles:

It is generally accepted that parenting is difficult under the most ideal circumstances of two-parent family, economic stability, health and so on. Frequently the single mother needs to work outside the home for financial support for herself and children.

For those who had partners at first, the adjustment to living from one source of income is extremely difficult. Others who were dependent on the other spouse for a living find it even more difficult to live economically. Many of the single adults have lost their possessions and others are bankrupt. It is quite common that single adults are especially susceptible to uncontrolled finances due to the lack of accountability to any other person (Mayo, 1987:263). Loss of the husband's contribution is counterbalanced to some extent by new sources of finance, such as child support. Divorced women sometimes want to remarry for monetary reasons since they are economically less satisfied with their lives. That is why, according to Seccombe and Warner (2004:292), many people have argued that marriage is beneficial, because it brings a more secure financial position for the households. Some singles experience financial difficulties which they cannot solve on their own. Taking care of the household becomes a burden for some divorced and widowed women, because they generally have fewer sources of income than those who remain married (Morgan, 1991:29).

\subsection{Unfaithful sexual relationships}

In many cases single people feel the same sexual desires as married people. This means that they sometimes have men who will live with them as their boyfriends just for the sake of sexual satisfaction. Being involved in a marriage allows a woman to explore her sexuality and establish patterns of sexual activity. That is why Koons and Anthony (1991:125) say that when the normal function of sexual intercourse "is interrupted by the end of a marriage, a considerable degree of personal adjustment must take place". A woman's new status as a single person may require her to re-evaluate her ethics, moral standards and values concerning sexual behaviour.

De Paulo (2006:147) has this to say: "Single women are either snivelling about their celibacy or recklessly pursuing sex in all the wrong places." That is why people who practise self-discipline are often considered strange indeed. According to Bird and Melville 
(1994:139), women tend to believe that sexual intercourse is an intimate activity that symbolises affection, trust and commitment. For the singles, sex is often separated from relationships of trust, commitment, mutual respect and caring, the context in which sexuality flourishes. This happens because the singles, says Scanzoni (1995:164), also want the same choices regarding sexuality as all other married people. Sexual intercourse was meant to be accompanied by trust, commitment, caring and so on, but if it takes place only for the sake of pleasure, it no longer fulfils its aims and objectives clearly and it becomes merely a way to obtain sexual release. Therefore, many singles also have sexually transmitted diseases, because they get involved in irresponsible sexual relationships.

Koons and Anthony (1991:126) explain that single mothers have a challenge of finding a substitute father who can serve as an appropriate role model for their children. This is an indication that some single women do not feel comfortable when they are completely on their own, but they need someone who will serve as a leading figure to them. This is also as a result of how they are treated in the community. However, this could differ from the situation of single men. There are men who claim to be of assistance towards the financially incapable single women, meanwhile they want to use them to satisfy their sexual desires, which is another form of abuse (Dickerson, 1995:89).

\subsection{Withdrawal}

It is not uncommon to see that in the face of rejection people build a wall around themselves. They succumb to the false option of running away from the issues and problems that surround them. Some singles believe that if they move and change their geographic location, they can start afresh somewhere else and the problems and realities of what is going on in their lives will not exist in a new locale.

Koons and Anthony (1991:115) elaborate: "They very often will withdraw into themselves, into their homes, and become reclusive, rejecting all attempts of others to reach out to them in a warm, caring, understanding relationship." Collins (1988:320) comes to a similar conclusion: "Lowered self-esteem and inferiority may contribute to social withdrawal."

Note the relationship between the issue of self-esteem and the issue of withdrawal here. Very often single people will not speak when 
they are in a group. This is one sign of withdrawal. Furthermore, they also often do not like to participate in public activities and they tend to avoid being with friends who are married.

Let me share some experiences that I had with some of the single women in our community. Some christian singles indicated that when married women talk about their husbands or their marriages they feel stigmatised and they have nothing to contribute, because they do not have husbands themselves. They, therefore, decide to keep quiet. In this way they withdraw from discussions, because they feel that the topic under discussion is another form of insult to them. This means that Reynolds (2008:123) is right when he says that social conversations about partners may be experienced as excluding by those who have none.

A pastor came to facilitate a certain women's workshop and on his arrival at the venue he greeted the women who were waiting at the entrance. When greeting the first woman he used the title "Mrs" since she was married, but for the second one he used the title "sister" since she was not married. I later noticed that the second woman whom the pastor had greeted was not actively participating in the workshop. I asked her about it and her response was: "I withdrew, because I felt the pastor did not acknowledge my womanhood because I am single. His way of greeting indicated that some were women while others were sisters in that workshop." This woman felt that this distinction was not fair, as they all belonged to the same church and were all women. According to her, it would have been better for the pastor to have called them by their names rather than their titles. I then realised that had the pastor greeted them both as "sister" the single woman would not have had a problem. This shows that how we address single people can also stigmatise them and that this may cause them to withdraw socially. According to Kapasula (2009), the English language enhances the stigmatisation of single women, because titles like Mrs and Miss indicate the difference between married and unmarried women.

Another reason for withdrawal by some is that they are suspected of poaching other people's husbands. In a radio programme called Bibele yi ri yini (2009) (literally: what does the Bible say) a woman phoned and said that she and other singles did not have a good relationship with married women, as these other women suspected them of tempting their husbands into relationships with them. Phaswana (2005:1) found in his research among Venda people that besides the fact that christian communities do not see any positive contribution that a single woman can make, they are also seen as 
people who chase and incite men. In this way they are suspected to be responsible for causing divorces in other marriages.

This issue is also raised by Southwood (1992:50) when he says that a divorced person

... can be very disruptive. There is not only the perceived threat that a single person could be on the brink of poaching sexual partners, but your very existence also throws uncomfortable questions about sanctity, or even the reason, for their own marriage.

These two issues highlighted indicate that there is a problem between single women and married women. This obviously causes singles to withdraw their life and friendship from the people who suspect them of such bad behaviour.

\section{How can pastoral work help single people?}

\section{1 Imago dei}

Calvinism teaches us that it is through faith in Jesus Christ that we are justified and made new creatures. It is by the grace of the Lord that we may be called his children and by no other condition. The Holy Spirit's power changes us from being strangers to the kingdom of God into being heirs of the kingdom. Single people must understand that it is on that basis that they become one with Christ and enjoy the benefits of the kingdom of God.

The very first point of departure in counselling single people is to accept them as images of God. The reason for this is that since these people have been stigmatised and marginalised and their image tarnished, they first need to be made aware that they were created in the image of God, irrespective of what they are. This can help to open up their willingness to discuss all issues that surround their single life. According to Baloyi (2007:205), for people whose image was violated by any means, the first pastoral responsibility is to help them therapeutically to realise the importance of being God's image.

This argument has its roots in the reasoning of Wimberly (1999:54) who maintains that many people

... bring to church and pastoral counselling a belief that God has abandoned and forsaken them. Deep down inside they harbour a thief who is robbing them of their self-esteem and hopeful 
outlook on life. Therapy must help them revive the feelings of God's presence in their lives.

In other words to turn the hopeless into the hopeful needs a realisation of people as God's image. When the Bible teaches us that human beings are made in the image of God, it does not say anything about marriage or single life as a condition. Nyirongo (1994:32) purports that the concept "image of God" should be understood in terms of people's relationship with God as their Creator and Father.

\subsection{Teaching that singleness is a legitimate choice}

To avoid the fact that many of the teachings in some churches are biased (mainly towards married people rather than single people), those churches which lag behind in how they deal with single people should now start to model positive attitudes and develop programmes that foster acceptance of singleness as a genuine option. The argument is that without weakening family and marriage programmes, some aspects must be incorporated to teach singles so that they also feel accepted. My understanding is that being single is sometimes not only tolerable, but even good.

It should also be well understood that teaching about being single does not replace or substitute the teaching about discipline. It is not meant to create an impression that single people are not expected to live a christian life as expected by God within the Bible. Rather, they still need to know that God wants them to live according to the demands of his law. The law that says: "Thou shalt not commit adultery" (Exod. 20:14, KJV) should not have exceptions when applied to single people. The church should, therefore, not shrink from the teaching that selfdiscipline is healthy. Only a disciplined person can love God in the way He commands.

Those being counselled in this regard need to understand that even though other people may judge them by their own principles regarding singleness, this is not a true test or reflection of their value. No one is able to please everyone all of the time and therefore, selfworth should not be measured by performance, because we all ultimately fail. It is very true that God, the Creator, bases our value on our personhood, not our performance. This is what Fagerstrom (1996:77) means when he says that we should not look to others for approval and self-esteem, but to the One who created us. Being a single person does not necessarily imply that he/she committed a 
particular sin or wrongdoing, but that there are instances in which that person was not fortunate enough to be coupled.

With regard to sexual temptations in counselling singles, there are many things to discuss. The first important thing to mention is to make sure that they understand the fact that being single is not a curse, as many seem to think. Regarding the issue of loneliness, we need to be careful to address it only if it is the loneliness that is related to or caused by being single, but if it is from other causes, the issue does not need to be included.

\subsection{Marriage does not remedy lust}

Since the need for sexual relationships is one of the problems faced by singles, it would be irresponsible not to address this challenge in this article. Hsu (1997:153) argues that theology of singleness includes a healthy theology of sex. For him the first step to a healthy approach towards sexuality is to recognise that sexual expression is not essential for life. In other words, single people need to know that sexual intercourse is not everything in life, nor is it a must. People can lead a good life with or without having sex.

The danger is that a person who gets married for the sake of intercourse might be disappointed later. Sexual intercourse is a small part of our whole lives, so singles should be encouraged to enjoy other things in life irrespective of whether they have sex or not. Pastors and counsellors must help singles realistically anticipate the problems and then offer methods and support needed to help them live righteously. The teaching that God commands a righteous life from all his children, regardless of whether they are a couple or single, must be emphasised.

The church leadership, particularly pastors, must learn to know all the forms of fornication that can be used instead of a life of pure singleness. Collins (1988:248) mentions four of the forms, namely homosexuality (lesbianism), masturbation, premarital and extramarital sex which are the most common means of sex for singles to experience sexual release. He continues to say that if at least one of the four forms mentioned is applied, thus deviating from God's plans for human beings, it is destructive. It is an undeniable truth that sex inside the marriage is meant to please the two people involved and strengthen their relationship, but sex outside the marriage will not yield any of the results required by the Bible. Therefore, if singles understand clearly what God's intentions with sex are, the better they will refrain from misusing sexual intercourse. 


\subsection{The church and singles}

The church as an institution is called to minister to the unique needs of the single-parent family. The first thing for the church is to identify these families and also try to find out the causes of the parent being single, as there are many different causes. This will enable the church to minister effectively to different individuals according to individual needs and problems. According to Koons and Anthony (1991:134), besides inviting singles to participate in all its regular programmes, a local church can help by developing specific support groups that will enrich their lives and strengthen them for meeting their unique challenges.

The church must also be counselled and taught to be prepared to provide them with a supportive and caring climate of acceptance. When the local church encourages singles to participate in its regular programmes, it must help by developing recreational outings, seminars, widowed recovery programmes, small groups for counselling, job counselling, single parenting, et cetera. Church leaders should help them to develop a variety of sharing and growth groups for singles. Widows to widows support groups, retreats, classes and workshops are also possibilities (Koons \& Anthony, 1991:133).

It is through these workshops that the church leadership will be able to also teach the entire congregation to know that social conversations about partners may be experienced as stigmatising and marginalising by singles (Reynolds, 2008:123). This means that the congregation members must be taught how to address the singles in a way which will make them feel acceptable and accommodated.

In churches where women are ordained to take particular responsibilities in the church, the church leadership must not discriminate against single women. Rather, selection of these women must take place according to the gifts and needs of the church. In other words, single women must also be allowed to take leadership roles just like all other women.

The fact that some christian communities do not acknowledge that singles can make any positive contribution, may be a result of the negative sermons about singles. Preachers should learn to accommodate all church members, singles included. Sermons that do not look at the whole Bible create a sense that the Bible is contradictory. For instance, in Genesis 2:18 we read: "It is not good for a man to be alone." If preachers preach only from this text, it would automatically create uneasiness towards singles, but this would contra- 
dict 1 Corinthians 7:1 which says: "It is good for a man not to touch a woman." Some sermons condemn singleness and illustrate that single people should look for suitable mates. It was good for Adam and others to have companions, but it was also good for Jesus and Paul to be single.

\title{
5.5 Financial assistance
}

There are those whose singleness is clouded by poverty and a lack of economic resources. The church's responsibility is not to watch the poor and hungry singles perishing, but it must do as Koons and Anthony (1991:134) say:

\begin{abstract}
A final requirement for the church towards the singles is to provide economic assistance to the best of its ability. The early church was known for its generosity towards those in financial need. Although the universal church can hardly eliminate the need for all state and federally funded programs local congregation can assist single parent families in practical ways such as: sponsoring a child with school fees, subsiding housing or grocery needs.
\end{abstract}

In cases of unemployed singles, community projects and economic empowerment can rescue the situation. They also need to be encouraged to work and start small businesses which will enable them to meet the needs of their families. Churches can also help them to start those businesses, while also helping these singles to seek employment. This financial assistance may help in the sense that those women who are forced to marry (by circumstances) for financial reasons will be liberated.

\section{Conclusion}

The issue that female singleness has been neglected and undermined is very common in most of our communities and churches. That is why most singles withdraw from active participation in the community while others do not regard themselves as important. Others do not trust male figures and, therefore, they cannot relate to them very well. With the pastoral guidelines above, the issue of structuring programmes by the churches and teaching the singles on how they should conduct themselves must become a priority. It should also be understood that some are not singles because they choose to be, but God made them as such and hence they should be accepted by both the community and the church. Teaching, rebuking and reproaching the church and the community about changing their attitudes towards singles is also very important. Any 
form of discrimination against singles should be condemned and denounced at all costs.

\section{List of references}

ANON. 2005. Gang raped woman in Bethal. Sunday sun: 31, 24 Jul.

ANON. 2007. Where am I wrong when I beat my wife? City press: 10, 18 Feb.

BALOYI, M.E. 2001. Counselling christian Shangaans on choosing a marriage partner. Potchefstroom: PU for CHE. (Unpublished M.A. dissertation.)

BALOYI, M.E. 2007. Patriarchal structures, a hindrance to women's rights. Pretoria: Tswane University of Technology. (Unpublished Ph.D. thesis.)

BIBELE YI RI YINI. 2009. Munghana Lonene radio programme, 17 May.

BIRD, G. \& MELVILLE, K. 1994. Families and intimate relationships. New York: McGraw-Hill.

COLLINS, G.R. 1988. Christian counseling: a comprehensive guide. Rev. ed. Dallas: Word.

DE PAULO, B. 2006. Singled out: how singles are stereotyped, stigmatized and ignored, and still live happily ever after. New York: St. Martin's Griffin.

DICKERSON, B.J. 1995. African American single mothers: understanding their lives and families. New Delhi: Sage.

DREYER, J.S. 2009. Holistic pastoral ministry and the challenge of violence against women. Paper delivered at the Joint Conference of Academic Societies in the Fields of Religion and Theology, Stellenbosch, 22-26 June.

ENGELBRECHT, R. \& WENTZEL, A-M. 1999. Divorce: a South African guide including a do-it-yourself section. Rivonia: Zebra.

FAGERSTROM, D.G. 1996. Counselling single adults: a handbook of principles and advice. Grand Rapids: Baker.

HSU, A.Y. 1997. Singles at the cross-roads. Downers Grove: InterVarsity.

HSU, A.Y. \& ROSENZWEIG, P.M.R. 1992. Married and alone. New York: Insight Books.

KAPASULA, J.K. 2009. Patriarchy and the oppression of African women in the 21st century: conversation with Adichie and Dangarembga. (Unpublished lecture at Unisa, 12 August.)

KIMATHI, G. 1994. Your marriage and family. Potchefstroom: Institute for Reformational Studies. (Series F2. No. 58.)

KOONS, C. \& ANTHONY, M. 1991. Single adult passages: uncharted stories. Grand Rapids: Baker.

KRIEL, J.D. 1991. Traditional marriages amongst blacks. Lantern, 40:27-29, Aug.

LANDMAN, C. 2007. Doing narrative counselling in the context of township spiritualities. Pretoria: Unisa. (Unpublished D.Th. thesis.)

LANDMAN, C. 2009. Religious identity of migrant farm workers in Hoedspruit, South Africa. Forum missions, 5:171-185.

MAYO, M.A. 1987. A christian guide to sexual counselling. Grand Rapids: Zondervan.

MONAGHAN, A. 1991. Counselling as a christian challenge. Dublin: Gill \& Macmillan.

MORGAN, L.A. 1991. After marriage ends: economic consequences for middlelife women. London: Sage. 
NICHOLSON, V. 2007. Singled out: how two million women survived without men after the First World War. New York: Viking.

NYIRONGO, L. 1994. Should a Christian embrace socialism, communism or humanism? Potchefstroom: Institute for Reformational Studies.

PHASWANA, D.R. 2005. Counseling singles. Sibasa. (Unpublished paper read in the meeting of reformed pastors.)

REYNOLDS, J. 2008. The single woman. London: Routledge.

SCANZONI, J. 1995. Contemporary families and relationships: reinventing responsibility. New York: McGraw-Hill.

SECCOMBE, K. \& WARNER, R. 2004. Marriages and families: relationships in social context. Belmont: Thomson/Wadsworth.

SMITH, C.S. \& SMITH, H.B. 2008. Why women shouldn't marry: single by choice. New Jersey: Barricade.

SOUTHWOOD, C. 1992. Newly single: an approach to life after marriage. Berkshire: Cat.

WICKS, R.J. \& PARSONS, R.D. 1993. Clinical handbook of pastoral counselling. Vol. 2. New York: Integration Books.

WICKS, R.J. \& PARSONS, R.D. 2003. Clinical handbook of pastoral counselling. Vol. 3. New York: Intergration Books.

WIMBERLY, E.P. 1999. Moving from shame to self-worth: preaching and pastoral care. Nashville: Abingdon.

\section{Key concepts:}

Ioneliness

self-esteem

singleness

withdrawal

\section{Kernbegrippe:}

eensaamheid

enkellopendheid

onttrekking

selfbeeld 